\title{
AN'TITRUST IN EUROPE: NATIONAL POLICIES AFTER 1945
}

\author{
HaNs B. Thorelli*
}

This is the second in a series of three lectures entitled "Antitrust in Europe" delivered at the University of Chicago Law School in the autumn of 1958.1 The first lecture was devoted to the social economic, political, and legal environment in Europe during the period 1915-1945, on the premise that a fairly thorough discussion of that environment was essential to any understanding of public policy toward monopolistic phenomena and practices. That lecture supported the following conclusions: The three decades comprising the two World Wars may be characterized as an era of cartelization. This reaction against the ideas of economic liberalism which had originated in that same part of the world one hundred and fifty years earlier was motivated by a number of powerful factors: the great wars, the depressions, economic philosophies of the stagnationist variety, political ideologies of a totalitarian ilk, and a widespread pessimism resulting from the realization that whoever won the first war, Europe as a whole lost. Wartime mobilization efforts fostered a climate of restriction and regulation which lingered on well into the twenties. That decade, less than roaring in most nations of Europe, was followed by the Great Depression, which even in this country temporarily fostered a cartel system, the NRA. Stagnationists and pessimists alike preached the merit of holding on to what one already had: any change was probably for the worse. Nazis and fascists sponsored the corporate state, in which each sector of the economy was governed by cartels or similar groups. Other nations found themselves grasping after public and private regulatory schemes in self-defense against the economic warfare of totalitarian states. Cartelization reached a logical climax in World War II.

During this era businessmen were prone to talk about the stabilization of markets and the rationalization of industries on a collective basis, and about the necessity of avoiding the wastes of competition. Free enterprise did not signify in Europe a business economy inside of which freedom prevailed, but stood for the desire of business to keep the government from exercising public control over economic life. Labor in most countries, while blasting monopolies and cartels as evils of capitalism, welcomed them as ultimately facilitating the "expropriation of the expropriators." Conservatives and socialists alike stood for regulation (the quarrel was merely who was to regulate whom), while liberals in rank and infuence represented a lost generation.

Such a background was not conducive to radical departures in the field of monopoly policy. In Britain the common law doctrines against monopolization and restraint of trade had had their teeth pulled before World War I, and in the inter-war period that nation, as well as those on the continent, abided by the principle of Roman Law emphasizing the sanctity of any contracts not clearly criminal in nature. Statutes against unfair competition were directed against such practices as bribery and misleading advertising rather than against monopolistic practices.

In some respects the environment thus depicted has undergone significant change in the last ten or fifteen years. Appreciating the dangers of generalization, one may still characterize the change as representing a rentewal of economic liberalism.

* Research Consultant, Marketing Services Research Service, General Electric Company.

1 The first lecture is summarized in the text. The third, on European participation in international efforts to control restrictive business practices, deal primarily with the Coal and Steel Community and the European Economic Community. The text of the first and third lectures will appear in 8 U. of Chi. L. S. Rec., No. 2 (1959). 


\section{REVIVAL OF LIBERALISM}

7 HE new brand of economic liberalism first appeared in a very general reaction against the enforced scarcities and regimentation of the war years and a concomitant interest in material progress and higher standards of living. The hostility to regimentation gradually matured into a new respect for private initiative and a recognition that competition need not be wasteful but, indeed, might be a powerful force working for economic growth and greater productivity. The liberalism also manifested itself in a new concern for the greatest possible liberalization of international trade. Indeed, the predilection for free international trade is a good deal more reliable in some European countries today than in the United States.

While there may be other underlying causes of the new and somewhat relativistic liberalism, two potent factors deserve mention: the enormous needs involved in reconstructing war-ravaged nations, needs which obviously could not be met by old-style restrictionism, and the education supplied by the United States under various aspects of the Marshall Plan. Direct pressure was applied to recipient nations to do away with the cartel mentality as at least a formal condition of obtaining American aid. In addition, most of the European productivity teams of business, labor, and government leaders sent to this country under the Plan were greatly impressed with the achievements of the American system.

A system of greater economic freedom, supported by governmental measures where necessary, also began to be advocated in some academic circles, notably in the Ordo School under the late German economist Walter von Eucken. Disciples of this school prominent in public life are Ludwig Erhard and the head of the new Federal Cartel Office of Germany, Dr. Eberhard Gunther.

Although the new liberal ideas have led to a certain renaissance of liberal political parties, it is even more significant that those ideas have quite noticeably infiltrated the ideology of both labor and conservative parties, still the most powerful parties in Europe.

Under the impact of the neo-liberal ideas public policy with regard to monopoly and restrain of trade has gradually become reoriented. This process has given no evidence of having reached a termination yet and has yielded a number of specific results in the past twelve years. Of this span the first half may be viewed as the period of tentative reconsideration. During that period the world witnessed the breaking up of some of the major German combines by the Military Government, the somewhat grudging acceptance of the anti-cartel provisions of the Occupation Statutes of Germany, the passage of a cartel registration law in Sweden in 1946, and the enactment of the Monopolies and Restrictive Practices (Inquiry and Control) Act in the United Kingdom in 1948.

But the main wave of legislation, not only in the countries just referred to but 
also in most other western European nations, has surged forth since 1952. In some instances the results have been remolded versions of prewar legislation, but it must be emphasized that-as far as this century is concerned-a public policy encouraging competition rather than restraint thereof is of very recent origin in Europe. This, among other things, makes it hazardous to venture a reasoned judgment as to the effectiveness of national policies.

\section{Comparative Analysis}

Before proceeding to an analysis of current West European approaches in the field of antitrust, two observations concerning the methods of comparative law should be made. The most popular method by far in the field of comparative law is first to examine the legislation of country $A$, thereafter the legislation of country B, then country $C$, and so on-in other words to make a series of separate case studies of national legislation. Apart from the obvious fact that this method tends to be less of a strain than other methods on the researcher, its principal strength is that it views each national piece of legislation as an integrated system. It is especially tempting to take this country-bycountry approach in studying restrictive business practices legislation in view of the amazing diversity of public policy in the area. However, this method has the weakness that it really does not involve any comparison at all. It only provides the basic materials for a comparison, but leaves the most difficult task, that of systematic comparison, to the reader.

The main alternative procedure, of course, demands a scheme of classification, a taxonomy on the basis of which meaningful direct comparisons may be made. Some efforts have been made in this direction in the comparative study of antitrust legislation. One approach has been to divide national legislative systems into those based on the notion of prohibiting restrictive business practices on the one hand, and those regulating or eliminating specific abuses of such practices on the other hand. A similar way of slicing the cake has been to examine public policy from the viewpoint of whether it is primarily preventive or primarily corrective in character. For example, the United Nations Ad Hoc Committee on Restrictive Business Practices made a comparative survey of legislation in which the following classification was used: (1) legislation providing for surveillance of restrictive business practices; (2) legislation requiring the adoption of such practices; (3) legislation providing for prevention and control of such practices; and (4) emergency legislation. It is admitted that none of these systems of classification is very good. To detail the objections would go too far afield, but it may be said generally that the categories used are so broad and overlap so much that they are of rather little value.

How, then, shall the methodological issue be tackled? Realizing that perfection is unattainable, one might prefer to make use of both major alternatives discussed above. However, space does not permit a survey of antitrust legislation nation by nation. Instead, attention will be focussed on a direct com- 
parative analysis using a taxonomy which, to a degree, is both novel and more satisfactory than its predecessors in this particular field of study. The taxonomy involves five categories: stated objectives, aims regarding the interaction of firms, approaches, scope, and enforcement.

A. Stated policy objectives.-The comparative analysis of West European laws will begin with an examination of the official aims of these laws as stated in their titles, preambles, or introductory sections. (Of course, reference could also be made to the legislative history of these statutes, but this has been deemed inadvisable, as the relative significance of such history as an indicator of legislative or governmental intent varies considerably from country to country.) The following are some of the passages in the laws seemingly intended to indicate the direction of public policy:

UNITED KINGDOxr: "the registration and judicial investigation of certain restrictive trading agreements"; "prohibition of such agreements when found contrary to the public interest"; "prohibit the collective enforcement of conditions regulating the resale price of goods." [Preamble of 1956 legislation.]

GERMraNy: "Law against Restraint of Competition." [Title.]

FRANCE: "to put an end to practices which by restricting fair competition in business, prevent any fall in prices." [Preamble.]

BELGIUN: "protection against abuse of economic power." [Title.]

DENMARK: "prevent unreasonable prices and conditions of trade and to safeguard the best conditions possible for the free exercise of trade." [Text.]

NoRway: The Norwegian law has an entire smörgåsbord of aims. The policy is to "promote full employment, efficient utilization of means of production, counteract crises in trade and promote a reasonable distribution of national income by $(a)$... counteracting prices, profits and terms of trade which have an unreasonable effect, (b) preventing higher dividends than are defensible, (c) safeguarding against undesirable conditions of trade or competition, and against restrictions on competition which are unreasonable or damaging to public interests." [Text.]

SwEDEN: "promoting competition in business such as is desirable from a public point of view." [Text.]

FINLAND: "prevention of damaging effects of restrictions of competition in business." [Text.]

It is readily apparent that the aims of these statutes have not been stated in terms making the legislation easy to compare. Some nations, by legislative habit, do not specify the general objective or underlying philosophy of their laws. Others prefer to state them in broad and vague terms: still others go into considerable detail. In some instances there is also an unmistakable tendency to think in rather grandiloquent terms in stating the objectives of policy. It is somewhat like declarations in favor of "sugar and spice and everything nice" or "wine, women, and song." With a sigh of cosmopolitan resignation, one finds it necessary to turn from the stated to the real objectives of the laws, knowing full well of the dangers of misinterpretation.

B. Aims regarding the interaction of firms.-The discussion will proceed 
by classifying the intended or incidental effects which the antitrust laws have on the organization of economic life; that is, the aims or effects of those laws will be considered in terms of the relationship and interaction between firms. While this may not be the only yardstick against which objectives can be measured comparatively, it is certainly an important one. The antitrust policies can be divided into four groups, depending upon the degree to which they affect competitive interaction: pro-competitive policies, policies with an ambivalent effect on competition, anti-competitve policies, and, finally, a-competitive policies-policies of indifference from the viewpoint of their intended effect on competition. The meaning of these terms may perhaps best be clarified by illustrating what kinds of approaches are used in various statutes for implementing the different policies. A pro-competitive policy may be implemented by such means as publicity, prohibition, dissolution, and invalidation of restrictive business practices. Policies with ambivalent effects on competition are manifested in laws based on the notion of fostering countervailing powers in the economy, or laws undertaking only ad hoc regulation of restrictions on trade, or laws which only aim at the regulation of specific types of such practices. An anti-competitive policy is exemplified by a compulsory cartelization law.

In the case of an a-competitive policy, the possible impact on competition is decidedly of secondary interest to the legislator. A law resulting from an acompetitive policy may include provisions for the certification or sanctioning of restrictive agreements under certain conditions, or for the continuous regulation of prices or of entire branches of industry or trade. While the preservation of competition as such is not recognized as a positive value in such cases, the legislator is usually conscious of the fact that he is intervening in the affairs of business by restructuring the ways in which competitors interact with each other.

While theoretically distinct, the criteria for classifying policies tend to overlap when applied against the background of real life. It must also be emphasized that to date this yardstick is of rather speculative value because of the limited experience under most European laws. Furthermore, a critic cannot fail to point out that logically there should be a supplementary scale dealing with aims regarding the interaction of firms not engaged in competition and, quite particularly, the relationship between producer and distributor. Nevertheless, it is felt that the scale even in its present form is reasonably inclusive and reasonably intelligible. Moreover, it has the advantage of improving understanding of the effects of the various instruments or approaches used to implement West European antitrust laws. It is readily admitted, however, that no nation clearly falls into any one of the categories mentioned. (Indeed, if one disregards the Sherman Act, the most clear-cut example of a pro-competitive statute in the world, it is submitted that not even American antitrust legislation is clearly classifiable in terms of its aims, and much less so in terms of its effect on competition.) 
When more is learned about the long-term effects, as contrasted with the legal verbalizations of European policies, one might well try to fit them into the suggested or some similar mold, classifying them according to the main emphasis of the law. However, for the time being most of the laws are too recent to permit this to be done meaningfully. Instead, a much more arbitrary ranking will be made along what may be called a sliding scale of friendliness towards competition. It must be kept in mind that this ranking considers only the formal legislative provisions of the various nations, and not the degree to which these provisions are enforced, nor the possibility that certain areas of the respective economies, such as socialized industries or public utilities, may be entirely withdrawn from antitrust legislation. Going from the "highest" to the "lowest" degree of friendliness to competition the nations of western Europe might rank as follows: Germany, Sweden, Britain, Denmark, Finland, France, Belgium, Ireland, Norway, Netherlands, and Austria. It must be emphasized that no exactness is claimed for this scale; while it is probably valid in indicating the part of the entire spectrum in which each national policy would fall, the specific ranking of one nation in relation to its immediate neighbor on this scale is necessarily quite arbitrary.

C. Approaches.-The third category in the suggested taxonomy is that of the main approaches or strategies which are being used to implement the objectives of national legislation. An attempt to indicate these approaches is presented in Table 1. In this table $\mathrm{P}$ stands for approaches given primary emphasis and $S$ for those given secondary importance. Before an analysis is made of Table 1 and the following tables, a number of reservations should be made. The borderlines between approaches of primary and secondary significance, for one thing, are rather vague. In several instances it seemed that more than one approach used in a given nation, for example, the United Kingdom, had to be labeled as primary. Furthermore none of the tables purport to be exhaustive. They are intended only to represent the cardinal features of national systems. Due to the many complexities involved in international comparison, it is not possible to vouch for all details. And, indeed, the list of variables in all the tables is strictly tentative. Without further research one cannot be certain of having settled upon the most relevant categories or the most clear-cut or instructive ones. It does seem that the analysis has been taken one step beyond that of the previous writers on comparative antitrust law, but perhaps it is a step onto thin ice.

In Table 1, the great variety of approaches used by West European countries has been divided into four major categories: publicity, prohibition, invalidation, and regulation. Readily apparent is a major cluster of primary interest in publicity. There is a considerable grouping of secondary interest in prohibition, with which has been lumped dissolution, and another cluster in different varieties of regulation, especially of the ad hoc type, by which is meant regulation dovetailed to what the enforcement authorities consider the special needs of each individual industry whose practices come under review. Invalidation, 
the favorite strategy of the old common law, draws only scattered support in contemporary European legislation.

It should be added that a special difficulty in making a classification at a time when national policies are only a few years old in most instances is that one really does not know yet whether an approach that on paper seems to be highly important will prove to be as significant in practice. For instance, no one yet knows with what intensity the United Kingdom will apply the alternative sanctions of invalidation and prohibition. Similarly, it is impossible to say at this time what the balance will be between the sweeping, Sherman-

TABLE 1

APPROACHES*

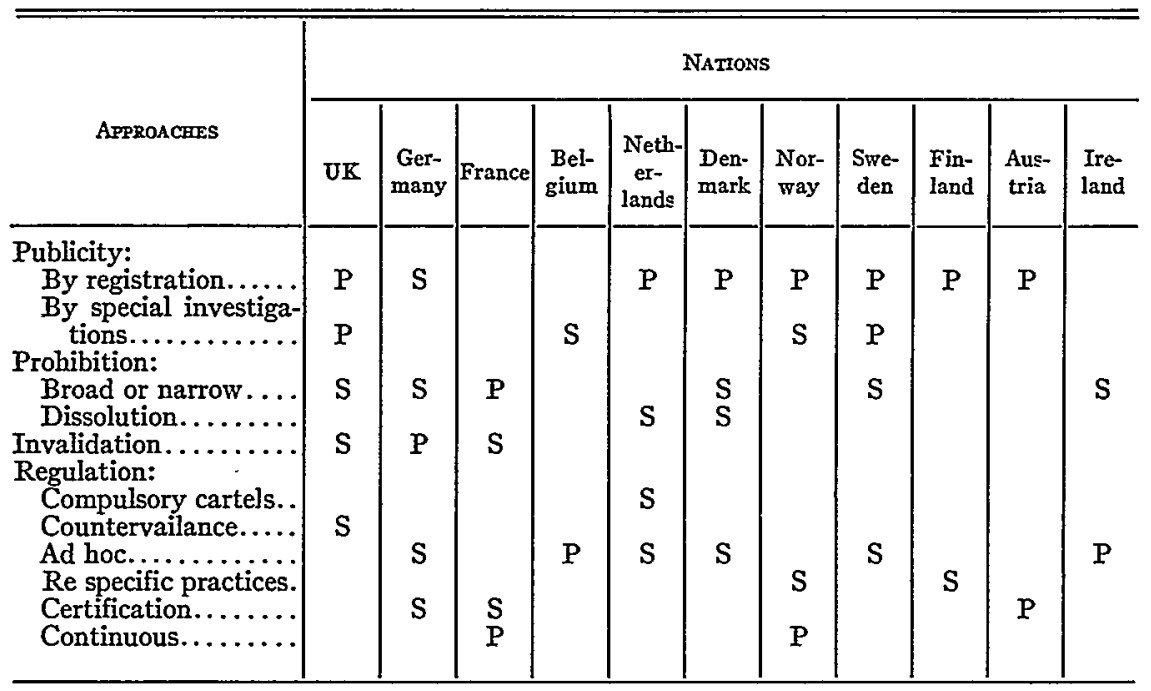

* P stands for what tentatively seems to be a primary approach, $S$ for what seems to be a secondary approach.

Act-inspired language with which cartel arrangements are made subject to invalidation by German law and the legion of exemptions by which such arrangements may in fact be authorized and surrounded with an aura of official approval.

D. Scope.-Table 2, which relates to the scope of legislation, is divided into two parts. The first deals with areas specifically within the purview of legislation; the second deals with matters explicitly or implicitly exempt from the operation of national antitrust laws. It is striking that all of the laws included are written to embrace cartel agreements. This, indeed, is the most important feature which European systems have in common. The table also lists approximately one-half of the nations as including single-firm monopolies or corporate combinations within the reach of their laws. It must be 


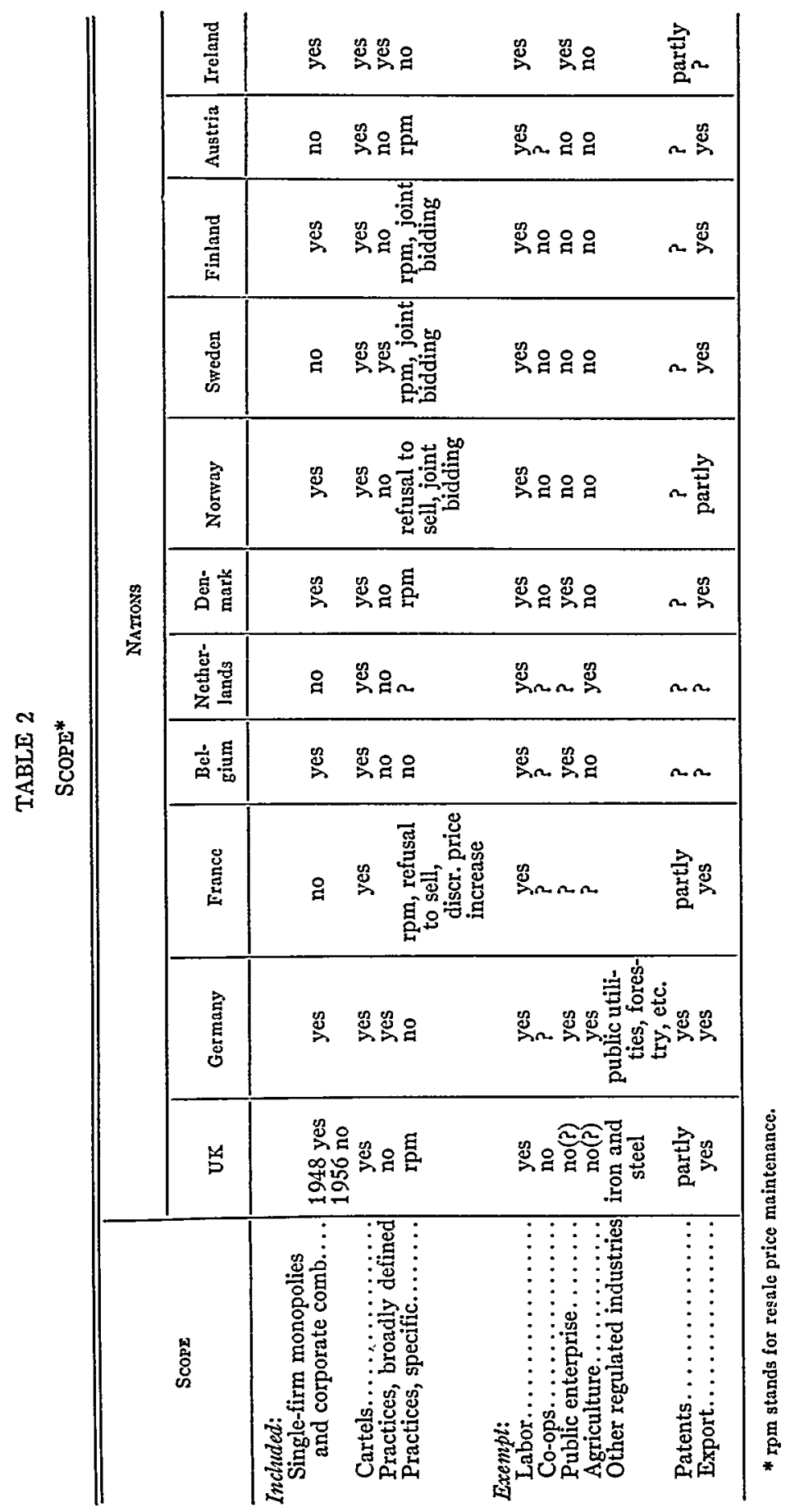


remembered, however, that the provisions aimed at single-firm combinations have less teeth in them, as a rule, than those designed to attack cartel problems. The reader may wonder why separate mention has been made of business practices, as such operations will necessarily be the subject of deliberation in any consideration of cartel cases. Their inclusion as a separate heading in the table is warranted by the fact that some nations have special regulation of specific practices or of competitive practices in general, whether engaged in by a small enterprise, a single-firm monopoly or a cartel. There is considerable diversity in the approach taken by various nations to the regulation of business practices. Most nations dealing with specific practices have regulations concerning resale price maintenance. Some of these also regulate joint bidding arrangements or refusals to sell. France prohibits discriminatory price increase-prices apparently move only one way in that country. There is rarely a blanket prohibition of any of these practices; that is, if there is a general proscription of a practice the law usually provides for exemptions under limited circumstances.

With respect to exemptions, it should be noted that labor union activities are universally excluded from the operation of European antitrust laws. This is due in part to the European impression that the application of American antitrust law to labor activities produced undesirable results, and in part to the fact that Socialist or Social Democratic parties have had a heavy hand in framing or supporting the European laws. In contast, cooperatives generally are not exempt from cartel legislation, despite their very strong position both as businesses and as pressure groups in such countries as the United Kingdom and Scandinavia. European laws tend to duck the issue between patent and antitrust legislation, in spite of the rich American experience on this point. The implications of the rather general exemption of restrictive business practices in export trade from the operation of national laws to the antitrust provisions of the European Economic Community and other past or potential international efforts to control restrictive business practices in trade between nations are discussed in another publication. ${ }^{2}$

The question marks in the exemption portion of the table represent in part at least a failure or an unwillingness of legislators to face up to the borderline issues. The vagueness about the critical fringe issues may be seen in its proper perspective when it is remembered that it took a long time to settle several of these issues in the United States. But it must also be admitted that some of the question marks indicate that not enough is known of the general background of the legislative systems of the nations involved to perceive how enforcement authorities will handle borderline problems. In some cases too, these problems may be regulated by other laws such as agricultural adjustment acts or laws governing specific public enterprises.

E. Enforcement.-The third table deals with enforcement. It is primarily

${ }^{2}$ See note 1 supra. 
concerned with the number and types of agencies involved in the enforcement effort, only secondarily with procedure, and not at all with sanctions. Although this considerably restricts the limits of analysis, it was found that there was too much variation between nations and, indeed, too many variations within nations regarding different types of action to make meaningful and practical a more detailed comparison of points of procedure. With respect to sanctions, it may be added that they coincide in large part with what was termed "approaches" in Table 1. The information on the private actions refers to the possibility of damage suits between private parties in the regular court system or to the existence of a statutory guarantee whereby any member of a cartel may withdraw at any time or at specified intervals without incurring any liability for damages or any other legal sanction.

Table 3 refers only to the mainstream of enforcement. A variety of procedures

TABLE 3

ENFORCEMENT

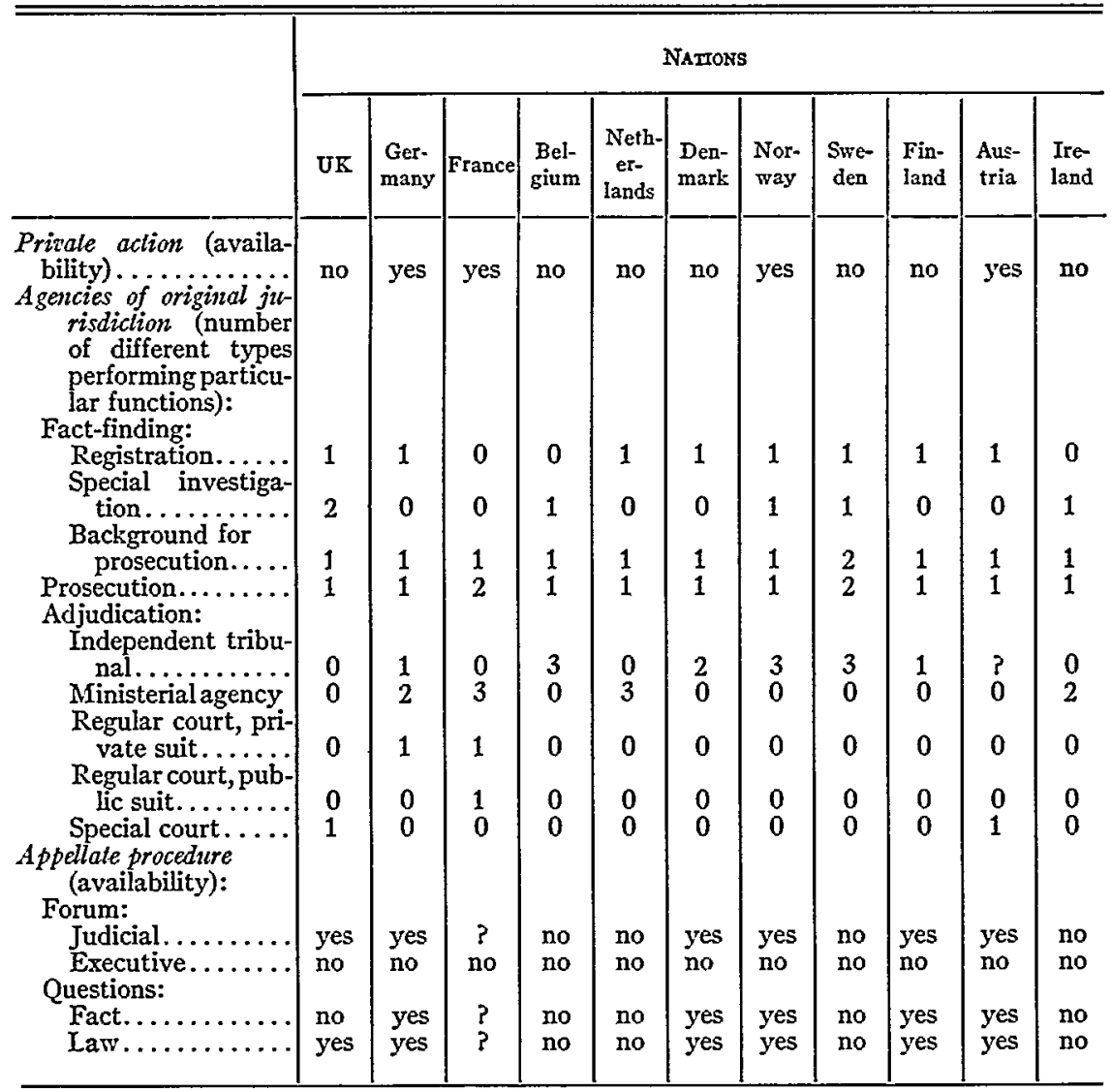


and devices are used in exceptional cases, and in some countries (Germany, for example) the number of cases handled by the exceptional procedures may well be greater than the number of cases handled by the procedure designated in the table. In gathering information concerning agencies of original jurisdiction, the author noted frequent overlap in particular agencies between the fact-finding and action stages. Adjudication, however, tends to be placed in the hands of agencies not concerned with the first two stages. The variety of tribunals used for adjudication is striking, although independent administrative bodies tend to be the most frequently designated type of agency.

It should be remarked that registration has a significance which greatly varies in different countries. In some nations all agreements must be registered, in others agreements need be registered only if the registration agency so requests. In the United Kingdom the register has the two-fold function of making agreements a matter of public record and supplying the basis for enforcement action. In that country all registered agreements must be considered by the Restrictive Practices Court. In Sweden, registration of itself means no more than that an agreement becomes a matter of public knowledge. There is no implication of any sanction; nor is it necessary that the registered contract be explicitly considered by enforcement authorities. In Austria, registration is virtually a certification of government approval of the restrictive agreements registered.

In the table, the term "special investigations" refers either to comprehensive studies of an entire industry or trade or to investigations into the existence and effects of particular restrictive trade practices. Analogues in the United States may be found in the many reports of the Federal Trade Commission on concentration in various industries, the prevalence of interlocking directorates, and similar subjects.

With regard to appellate procedure, it has been found that there is never a clear-cut right of appeal to ministers or cabinets by affected private parties, despite the fact that in some countries those executives have the power to overrule the decisions of lower tribunals in cartel cases. Only in the United Kingdom, Germany, Denmark, Finland, and Austria, moreover, is there any clear-cut right to appeal even in the regular judicial system. The rather limited right of appeal found in some countries, for example Sweden, must be considered in the light of the rigorous criteria specified for actions as well as decisions by the enforcement agency, the broad publicity surrounding the procedure, and the well-defined and quite limited powers of the enforcement agency. In such cases concern for the rights of citizens may not strongly demand the right of appeal, although this writer has advocated the inclusion in Swedish antitrust legislation of the right of appeal to the regular court system.

\section{SUMMLARY AND CONCLUSIONS}

A. Legislation. Some general observations can now be distilled from the details of the five classification schemes analyzed above. Before considering 
this summary, the reader should remember that the work accomplished to date has been only preliminary in nature. Thus, some of the observations made below may eventually prove to be overgeneralizations.

1. A striking common feature of Western European antitrust legislation is its emphasis on publicity. This feature is especially noteworthy because publicity about business relations is a great novelty in many of the nations in which business traditionally has been carried on behind a veil of secrecy. As discussed above, the most popular means of insuring publicity is the requirement that restrictive agreements be registered.

2. Though all legislation concerning restrictive business practices has its origin in the belief that at least some such practices are undesirable (and at least to that extent the legislation supports competitive forces in the economy), the degree of friendliness to competition varies markedly between different European nations. Nevertheless, there has been a remarkable breakthrough from the prewar notion prevalent in many of those nations that competition is basically an anti-social, disloyal, and generally destructive way of economic life.

3. There is nowhere to be found in West European antitrust legislation a general prohibition of all restrictive practices such as is contained in the Sherman Act.

4. All the antitrust laws concentrate on cartel arrangements.

5. European laws are not, as a rule, much concerned with single-firm monopolies or corporate combinations as such. The reluctance to attack such tight combinations probably stems from a rather widespread belief that there is a positive correlation between size and efficiency, a feeling that cartels constitute more of a barrier to progress than do individual combines, and a notion that most national markets in Europe are too small to allow optimum operation of even single firms in many branches of industry.

6. There is a fairly widespread interest in the regulation of specific restrictive practices, whether engaged in by cartels or by single firms. Particularly noteworthy is the European interest in resale price maintenance. While a few of the nations which have special fair-trade regulations go no further than requiring such agreements to be registered, the more usual practice is to prohibit fair-trading altogether, albeit with express exceptions for certain trades like book publishing. In some cases authority is vested in a public body to grant ad hoc exemptions. Regulation of resale price maintenance, incidentally, is a marvelous example of how crucial it is to view the law in relation to its particular task environment instead of making the rather sterile formal comparisons which are all too usual in this field. For instance, the Danish prohibition of resale price maintenance is likely to have a much greater effect on the entire Danish marketing system than a similar prohibition would have in the United States. In the latter country there is, comparatively speaking, such hectic competition between various forms of distribution that, even where resale price maintenance is permitted, rationalization of the distributive appara- 
tus is not stifled. In tight-knit little Denmark, on the other hand, resale price maintenance agreements traditionally were one of the most effective vehicles for the complete elimination of all competition in the field of distribution. Already the rather recent prohibiticn of this practice in Denmark has had a quite noticeable effect in promoting the growth of new forms of distribution, such as discount houses and supermarkets.

7. It is characteristic of European laws that they look to the effect rather than the intent of restrictive business practices in delineating the grounds for public action. Contrary to what might be expected, however, this emphasis on result rather than intent does not seem to make any easier the task of the enforcement and adjudication agencies. Frequently it is difficult to establish not only what the effects of a particular agreement are in the short and long runs but also whether such effects are compatible with the public interest, a very involved factor.

8. Activities of organized labor are exempt in all West European antitrust laws. Arrangements exclusively or primarily aimed at operations in export markets are, as a rule, also beyond the purview of national legislation. In the few instances where export arrangements are reached by the law, information about them is usually kept in secret files.

9. West European laws tend to leave only vaguely defined the relationships between antitrust policy on the one hand, and laws governing public enterprises, public utilities, and patents, on the other hand.

10. In all the West European nations special agencies, whether judicial or administrative tribunals, have been established to handle the enforcement of antitrust laws. The character and independence of these agencies vis-a-vis other governmental organs, however, vary greatly from country to country.

11. Action under national antitrust laws usually must be taken on the formal initiative of public officials, even if the action has been inspired by the complaints of private citizens. In only a few instances can private parties bring action before enforcement authorities unless the suit is to obtain approval of restrictive arrangements, which is part of the procedure in some countries.

12. Similarly, members of cartel agreements typically have no more right to withdraw from such agreements than they have to break any other agreement covered by the law of contracts. A few countries have, however, introduced special laws to facilitate the withdrawal by dissatisfied parties either unconditionally or at certain periodic intervals.

13. All West European enforcement agencies have broad investigatory powers including, usually, the right to subpoena documents, to hear witnesses, and to visit the premises of enterprises whose activities are under investigation. The issuance of a court order may be a necessary preliminary step to the exercise of some of these investigatory powers.

14. The rights of appeal under West European antitrust laws are generally quite limited. Where permitted, appeal almost always lies to regular or special courts rather than to the cabinet or an individual minister. 
B. Enforcement.-As every serious student knows, the enforcement of any piece of legislation is always a matter of degree. The question of the intensity and the effects of enforcement efforts in 'various European jurisdictions is, therefore, a legitimate one. However, it is very difficult to give a generalized answer to this question beyond the statement that in a majority of countries the legislation is too new to enable one to draw very meaningful conclusions.

It is possible to be fairly specific about the number of registrations in those countries which have practiced this procedure for some length of time. Thus, by February 1, 1958, the United Kingdom had collected some 1,850 agreements. In the Netherlands some 850 national agreements were registered by the end of $1956 ; 500$ of the 850 were straight price cartels. In addition, the Dutch had registered some 1,000 regional or local agreements. Denmark and Norway each had several hundred agreements and a few score dominant concerns on register. Sweden had 1,727 agreements on file as of May 1,1958. Of this total, however, 842 had ceased to be operative after registration. This proportion of voluntary dissolutions is far higher than that found in any other country.

Similarly, it is not too difficult to obtain information about the special investigations undertaken in those countries which rely on this procedure. A considerable number of such investigations have been undertaken in the United Kingdom since 1948 (when the Monopolies and Restrictive Practices Commission was established) and in Norway since the early 1920's when the registration procedure was established in that country. Sweden has had a score of studies of the competitive conditions in various industries since 1946.

It is much more difficult to be specific when it comes to a quantitative evaluation of the specific cases which have been the subject of adjudication. Indeed, there seems to be little sense in attempting to go into detail on this point in a comparative survey since so many of the laws are but a few years old. However, the general observation may be made that the number of cases in most countries is certainly not smaller than the number of actions brought under the Sherman Act during its first years of operation.

It is also difficult to determine the general effect of enforcement, let alone the effectiveness of the enforcement efforts in terms of the stated aims of national legislation, unless a very detailed study were made of each country's experience. Such an investigation would have to take into account not only what has been done under the antitrust laws but also the substantial variations in the size of the specifically regulated sectors of the particular national economies. The publicly owned or directly regulated sector is, for instance, extremely large in France and, in spite of American impressions to the contrary, surprisingly small in a country like Sweden. It would of course be necessary also in such an investigation to know what the nature and extent of restrictive business practices were before the introduction of legislation as compared with conditions subsequent to passage of the legislation.

It can at least be noted, however, that in many European countries enforcement agencies have been greatly preoccupied with the three related types 
of restrictive practices which may be labeled refusal to sell, boycotts, and exclusive dealing arrangements. On the other hand, price cartels, illegal per se in the United States, have often been disregarded by legislators and enforcements agencies in Europe, despite-or perhaps because of-their being quite common in that part of the world.

In conclusion, it may be said that it is probably the indirect effect of the mere existence of laws controlling restrictive business practices that is important. The great interest in these matters aroused by all the new publicity and the fact that legislators have expressed either a modicum of positive faith in competition or at the very least their concern over some of the more farreaching restrictions thereof are some of the main grounds on which can be based a prediction that West European economies will continue to grow more flexible, more competitive. ${ }^{3}$

\footnotetext{
${ }^{3}$ The chief basis for this prediction, other than the reasons advanced in the text, is the emergence of the European Economic Community and other plans aimed at the establishment of a common market in Europe of a size comparable to that presented by the American economy. See note 1 supra.
} 